\title{
In-process non-destructive ultrasonic testing application during wire plus arc additive manufacturing
}

\author{
Knezović, N. ${ }^{a,}{ }^{*}$, Dolšak, B. ${ }^{b}$ \\ ${ }^{a}$ Faculty of Mechanical Engineering and Computing, University of Mostar, Mostar, Bosnia and Herzegovina \\ ${ }^{b}$ Faculty of Mechanical Engineering, University of Maribor, Maribor, Slovenia
}

\section{A B S T R A C T}

Additive manufacturing is a technique which builds structures by depositing material in a layer-by-layer manner. Wire plus arc additive manufacturing technology also belongs into this group of manufacturing processes. It has been investigated in the last twenty-five years, although the first patent dates from 1925. Wire plus arc additive manufacturing uses existing welding equipment, an electric arc as the heat source, and wire as the feedstock. In this paper, we explain some basic process planning and implementation techniques, as well as the main advantages and disadvantages of the process. In addition, we discuss the potential of in-process non-destructive ultrasonic testing application to this process, in order to inspect the quality of the part while it is being produced, and to enable eventual repairs in-situ. Some authors have already presented the idea of non-destructive testing for AM products, and stated that ultrasonic testing could provide the most reliable results for detecting the lack of fusion, porosity, and other possible flaws. While researches so far were limited to post-process testing, this paper proposes the idea of in-process testing, which could provide a chance to find the flaws and the defects earlier in order to change the parameters in-situ, and avoid production of the whole part if it is already recognised as unacceptable. Despite some constraints, we believe the proposed method has great potential and represents a challenge worth investigating in more detail in the future.
\end{abstract}

\section{ARTICLE INFO}

Keywords:

Additive manufacturing;

Wire plus arc additive manufacturing;

Non-destructive testing;

Ultrasonic testing;

Repairs in-situ

*Corresponding author:

nikola.knezovic@sve-mo.ba

(Knezović, N.)

Article history:

Received 11 August 2017

Revised 1 February 2018

Accepted 7 May 2018

\section{References}

[1] Mehnen, J., Ding, J., Lockett, H., Kazanas, P. (2014). Design study for wire and arc additive manufacture, International Journal of Product Development, Vol. 19, No. 1-3, 2-20, doi: 10.1504/IJPD.2014.060028.

[2] Chen, D., Lu, B., Chen, G., Yu, W. (2017). Influence of the production fluctuation on the process energy intensity in iron and steel industry, Advances in Production Engineering \& Management, Vol. 12, No. 1, 75-87, doi: 10.14743/ apem2017.1.241.

[3] Vesenjak, M., Gačnik, F., Krstulović-Opara, L., Ren, Z. (2015). Mechanical properties of advanced pore morphology foam elements, Mechanics of Advanced Materials and Structures, Vol. 22, No. 5, 359-366, doi: 10.1080/ 15376494.2012 .736059$.

[4] Mohamed, O.A., Masood, S.H., Bhowmik, J.L. (2016). Investigation of dynamic elastic deformation of parts processed by fused deposition modeling additive manufacturing, Advances in Production Engineering \& Management, Vol. 11, No. 3, 227-238, doi: 10.14743/apem2016.3.223.

[5] Williams, S.W., Martina, F., Addison, A.C., Ding, J., Pardal, G., Colegrove, P. (2015). Wire + arc additive manufacturing, Materials Science and Technology, Vol. 32, No. 7, 641-647, doi: 10.1179/1743284715Y.0000000073.

[6] Ding, D.H., Pan, Z.X., Cuiuri, D., Li, H.J. (2015). Process planning strategy for wire and ARC additive manufacturing. In: Tarn, T.J., Chen, S.B., Chen, X.Q. (eds.), Robotic welding, intelligence and automation, Springer International Publishing, Switzerland, Vol. 363, 437-450. 
[7] Ding, D.H., Pan, Z.X., Cuiuri, D., Li, H.J. (2015). Wire-feed additive manufacturing of metal components: Technologies, developments and future interests, The International Journal of Advanced Manufacturing Technology, Vol. 81, No. 1-4, 465-481, doi: 10.1007/s00170-015-7077-3.

[8] Ding, D., Shen, C., Pan, Z., Cuiuri, D., Li, H., Larkin, N., van Duin, S. (2016). Towards an automated robotic arcwelding-based additive manufacturing system from CAD to finished part, Computer-Aided Design, Vol. 73, 66-75, doi: 10.1016/j.cad.2015.12.003.

[9] Ding, J., Colegrove, P., Martina, F., Williams, S., Wiktorowicz, R., Palt, M.R. (2015). Development of a laminar flow local shielding device for wire + arc additive manufacture, Journal of Materials Processing Technology, Vol. 226, 99-105, doi: 10.1016/i.jmatprotec.2015.07.005.

[10] Ding, D., Pan, Z., Cuiuri, D., Li, H., Larkin, N., van Duin, S. (2016). Automatic multi-direction slicing algorithms for wire based additive manufacturing, Robotics and Computer-Integrated Manufacturing, Vol. 37, 139-150, doi: 10.1016/j.rcim.2015.09.002.

[11] Ding, D., Pan, Z., Cuiuri, D., Li, H. (2015). A practical path planning methodology for wire plus arc additive manufacturing of thin-walled structures, Robotics and Computer-Integrated Manufacturing, Vol. 34, 8-19, doi: 10.1016/j.rcim.2015.01.003.

[12] Ding, D., Pan, Z., Cuiuri, D., Li, H., van Duin, S., Larkin, N. (2016). Bead modelling and implementation of adaptive MAT path in wire plus arc additive manufacturing, Robotics and Computer-Integrated Manufacturing, Vol. 39, 3242, doi: 10.1016/i.rcim.2015.12.004.

[13] Geng, H., Li, J., Xiong, J., Lin, X., Zhang, F., (2017). Optimization of wire feed for GTAW based additive manufacturing, Journal of Materials Processing Technology, Vol. 243, 40-47, doi: 10.1016/j.jmatprotec.2016.11.027.

[14] Adebayo, A., Mehnen, J., Tonnellier, X. (2013). Limiting travel speed in additive layer manufacturing, In: Proceedings of The 9th International Conference on Trends in Welding Research, Chicago, Illinois, USA, 1038-1044.

[15] Ding, J., Martina, F., Williams, S.W. (2015). Production of large metallic components by additive manufacture Issues and achievements, In: Proceedings of The 1st Metallic Materials and Processes: Industrial Challenges, Deauville, France.

[16] Shen, C., Pan, Z., Cuiuri, D., Roberts, J., Li, H. (2016). Fabrication of Fe-FeAl functionally graded material using the wire-arc additive manufacturing process, Metallurgical and Material Transactions B, Vol. 47, No. 1, 763-772, doi: 10.1007/s11663-015-0509-5.

[17] Brandl, E., Baufeld, B., Leyens, C., Gault, R. (2010). Additive manufactured Ti-6A1-4V using welding wire: Comparison of laser and arc beam deposition and evaluation with respect to aerospace material specifications, Physics Procedia, Vol. 5, Part B, 595-606, doi: 10.1016/i.phpro.2010.08.087.

[18] Wang, F., Williams, S., Colegrove, P., Antonysamy, A.A. (2013). Microstructure and mechanical properties of wire and arc additive manufactured Ti-6Al-4V, Metallurgical and Materials Transactions A, Vol. 44, No. 2, 968-977, doi: $10.1007 / \mathrm{s} 11661-012-1444-6$.

[19] Baufeld, B., Brandl, E., van der Biest, O. (2011). Wire based additive layer manufacturing: Comparison of microstructure and mechanical properties of Ti-6Al-4V components fabricated by laser-beam deposition and shaped metal deposition, Journal of Materials Processing Technology, Vol. 211, No. 6, 1146-1158, doi: $10.1016 /$ j.jmatprotec.2011.01.018.

[20] Ding, D., Pan, Z., Cuiuri, D., Li, H. (2015). A multi-bead overlapping model for robotic wire plus arc additive manufacturing (WAAM), Robotics and Computer-Integrated Manufacturing, Vol. 31, 101-110, doi: 10.1016/i.rcim. 2014.08.008.

[21] Donoghue, J., Antonysamy, A.A., Martina, F., Colegrove, P.A., Williams, S.W., Prangnell, P.B. (2016). The effectiveness of combining rolling deformation with wire-arc additive manufacture on $\beta$-grain refinement and texture modification in Ti-6Al-4V, Materials Characterization, Vol. 114, 103-114, doi: 10.1016/j.matchar.2016.02.001.

[22] Xiong, X., Zhang, H., Wang, G. (2009). Metal direct prototyping by using hybrid plasma deposition and milling, Journal of Materials Processing Technology, Vol. 209, No. 1, 124-130, doi: 10.1016/i.jmatprotec.2008.01.059.

[23] Guo, J., Zhou, Y., Liu, C., Wu, Q., Chen, X., Lu, J. (2016). Wire arc additive manufacturing of AZ31 magnesium alloy: Grain refinement by adjusting pulse frequency, Materials, Vol. 9, No. 10, 823, doi: 10.3390/ma9100823.

[24] Djemana, M., Hrairi, M. (2016). Modelling and simulation of impedance-based damage monitoring of structures, International Journal of Simulation Modelling, Vol. 15, No. 3, 395-408, doi: 10.2507/IJSIMM15(3)1.338.

[25] Krstelj, V. (2003). Ultrazvučna kontrola: Odabrana poglavlja, University of Zagreb, Faculty of Mechanical Engineering and Naval Architecture, Zagreb, Croatia.

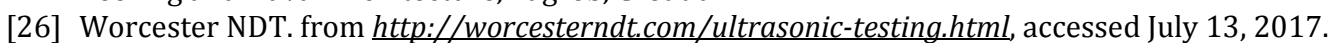

[27] Krautkrämer, J., Krautkrämer, H. (1990). Ultrasonic testing by determination of material properties, In: Ultrasonic testing of materials, Springer, Berlin, Germany, 528-550, doi: 10.1007/978-3-662-10680-8 34.

[28] Lopez, A., Bacelar, R., Pires, I., Santos, T., Quintino, L. (2017). Mapping of non-destructive techniques for inspection of wire and arc additive manufacturing, In: Proceedings of the $7^{\text {th }}$ International Conference on Mechanics and Materials in Design, Albufeira, Portugal, 1829-1844. 